\title{
Herbert Henri Jasper (1906 - 1999): An Appreciation
}

\author{
William Feindel
}

\begin{abstract}
Herbert Henri Jasper dedicated his life to studies of the brain in relation to the mind and behavior. He pioneered the application of the electroencephalogram (EEG) for the study of the electrical activity of the brain and used this technique in studies of consciousness, learning and particularly the examination of epileptic discharge. He utilized microelectrode recordings from single brain cells and combined this technique with microchemical analyses to study cortical and sub-cortical activity. $\mathrm{He}$ added substantially to our understanding of brainstem and thalamic reticular formations in conditions of consciousness and in relation to petit-mal epilepsy. His work with Wilder Penfield and associates over a quarter century elucidated the mechanisms of epilepsy and added to our understanding of the functional anatomy of the human brain. An enthusiastic and able organizer, Herbert Jasper was responsible for many international conferences on brain science and worked tirelessly to develop international collaboration among investigators of the nervous system, being one of the founders of the International Brain Research Organization and the Society for Neuroscience. His prodigious contributions in basic and clinical research will be recognized by the world community of brain science for years to come.
\end{abstract}

\begin{abstract}
RÉSUMÉ: Herbert Henri Jasper a consacré sa vie à l'étude du cerveau et à sa relation avec la conscience et le comportement. Il fut le pionnier de l'électroencéphalogramme (EEG) servant à l'étude de l'activité cérébrale électrique et a employé cette technique dans différentes études sur la conscience, l'apprentissage et particulièrement la compréhension des décharges épileptiques. Il a utilisé les données captées par micro-électrodes à partir cellules individuelles du cerveau et a combiné cette technique à des analyses micro-chimiques influencées par l'activité corticale et sub-corticale. Il fut d'une aide considérable à notre compréhension des formations réticulaires du cerveau dans le conscient et concernant l'épilepsie surnommée petit-mal. Son travail de recherche avec Wilder Penfield et ses associés pendant plus d'un quart de siècle a élucidé les mécanismes de l'épilepsie et a contribué à une meilleure connaissance du fonctionnement et de l'anatomie du cerveau humain. Un organisateur d'expérience et démontrant toujours de l'enthousiasme, Herbert Jasper a été responsable de plusieurs conférences internationales sur la science du cerveau et a travaillé inlassablement à développer une collaboration internationale entre rechercheurs sur le système nerveux, étant lui-même l'un des fondateurs de International Brain Research Organization and Society for Neuroscience. Sa prodigieuse contribution à la recherche clinique sera reconnue par le monde de la science sur le cerveau pour des années à venir.
\end{abstract}

Can. J. Neurol. Sci. 1999; 26: 224-229

During the span of 70 years which he devoted to examining the mysteries of the nervous system, Herbert Jasper was psychologist, physiologist, anatomist, chemist and neurologist (Figure 1). In addition to his research studies, he became deeply involved as teacher, director of laboratories for electroencephalography and neurophysiology, founding editor of the EEG Journal, founding member of the Eastern EEG Association and of the American EEG Society of which he was the first President. In the early 1960s he dedicated his organizational talents to the formation of the International Brain Research Organization (IBRO) that was linked to UNESCO and served as its first Executive Secretary in Paris.

Herbert Jasper listed the influences that led him to make a firm commitment at about 20 years of age to devote his life to brain research in all of its aspects. He cited especially the exciting developments in the late 1920s and early 1930s in brain sci- ence - the work of Erlanger and Gasser on nerve action potentials, the discovery of EEG by Berger and of the chemical nature of the synapse by Dale and Loewi. Herbert describes how his father "was somewhat dismayed for he wondered how I was going to make a living, because I was neither interested in studying medicine to become a doctor, nor in becoming a university professor!"] Herbert eventually became both - and much more.

Born in La Grande, Oregon on July 27th, 1906, Herbert Jasper was strongly influenced by his father, whom he described as a "thoroughly dedicated minister who excelled in mathematics and philosophy as well as practical engineering". 2 His great-

From the Montreal Neurological Institute and Hospital, Department of Neurology and Neurosurgery, McGill University, Montreal.

Reprint requests to: William Feindel, Montreal Neurological Institute, 3801

University Street, Montreal, Quebec, H3A 2B4 


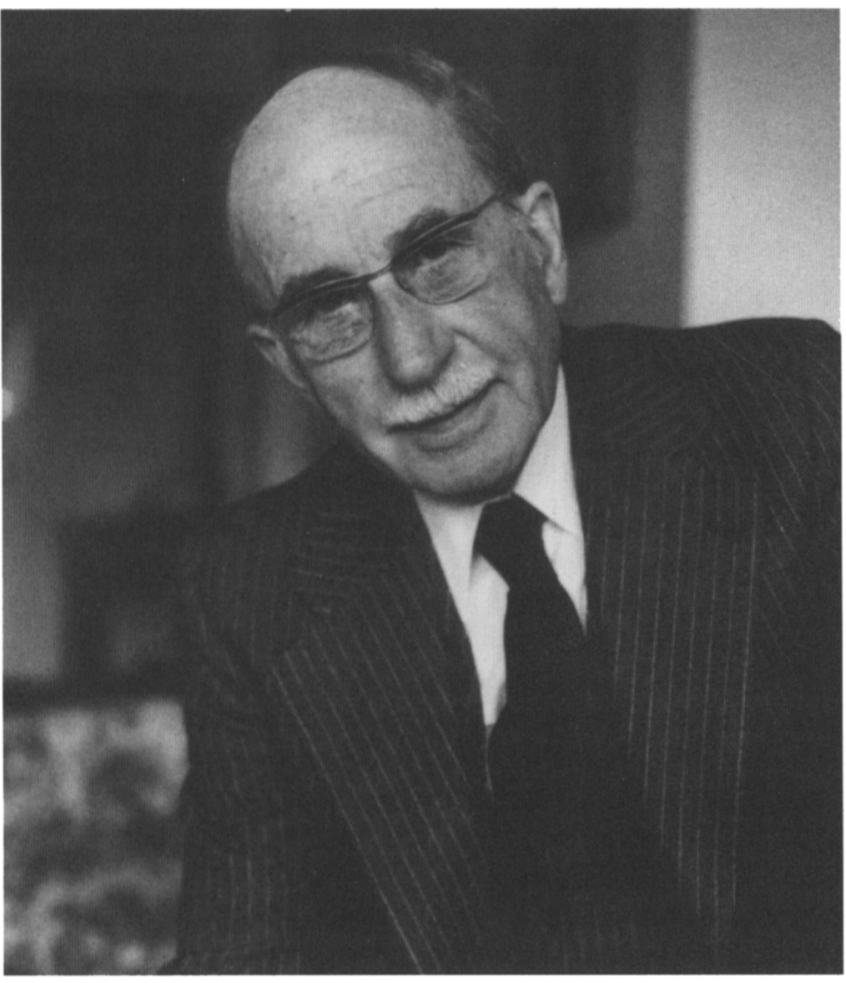

Figure 1: Portrait of Herbert Jasper, 1984.

grandfather had trekked by covered wagon from the eastern United States to Oregon country. His mother came from French Huguenot ancestors who had fled in the 1700 s to the Rhone Valley at the foot of the Swiss Alps. Two hundred years later, Herbert's Huguenot forebears also came to America and eventually to the northwest. He felt sure that this background of "pioneer genes" was of importance in determining his career in the neurosciences, when considered with early environmental influences. He has left for us inimitable accounts that throw light on his early education and how he became more focused on the physiology of the nervous system, with a driving interest in elucidating the mechanism of epilepsy that he pursued in partnership with Wilder Penfield over a quarter-century at the Montreal Neurological Institute. ${ }^{3} \mathrm{He}$ recounted his later career when he concentrated on the combined method of electrochemical analysis of neuronal activity. ${ }^{2}$
Gloor has noted, in a critical analysis of Jasper's rich contributions to neuroscience, that from the very beginning Jasper's aim had always been "to use the EEG as a means to investigate fundamental aspects of brain function, rather than to merely employ it as a diagnostic test". Gloor continued, "In spite of the fact that his quest had ultimately led him to a search for molecules, Jasper never lost sight of his original goal. He always hoped that research directed at fundamental and even molecular mechanisms in the brain may help us to better understand the human mind." 4 In discussing Jasper's views of the modern concept of epilepsy, van Gelder ${ }^{5}$ referred to "his dogged, untiring attitude and determination in the laboratory to master any new experimental approach which might be helpful in his search for greater scientific knowledge..." He puts Jasper's work in context of the neurochemical mechanisms underlying epilepsy, particularly the role of GABA and glutamic acid and the relation of these findings to the scientific basis for anticonvulsant therapy. ${ }^{5}$ Penfield gave a moving tribute to Herbert Jasper's "brilliant creative contributions to science at the Montreal Neurological Institute". He praised Jasper for the productive period of their work together over 25 years which culminated in their masterpiece, Epilepsy and the Functional Anatomy of the Human Brain that appeared in 1954 and summarized their extensive experience in the surgical treatment of seizures. ${ }^{6}$

\section{Early education}

Herbert Jasper was educated at six universities - four in the western United States, then at the University of Paris and finally at McGill in Montreal. A keen student of philosophy in his undergraduate days, he majored in psychology for his next three degrees, obtaining his doctorate in that subject from the University of Iowa in 1931. Before that, while at Willamette University in Salem, Oregon, he worked at the State Mental Hospital where he was able to join the clinical conferences and meet with the patients. He became astounded by the strange distortions in thought and behavior in these patients, for whom there seemed to be little or no treatment, only good custodial care. Herbert later mused, "What disturbances in brain function could underlay such tragic derangements in mental activity and behavior, was a question that has haunted me all my life". 1

His thesis at Reed College in Portland, Oregon, based on a questionnaire study of university students, resulted in his first publication, "Optimism and Pessimism in College Environments". A brief personal experience with the hallucinogenic

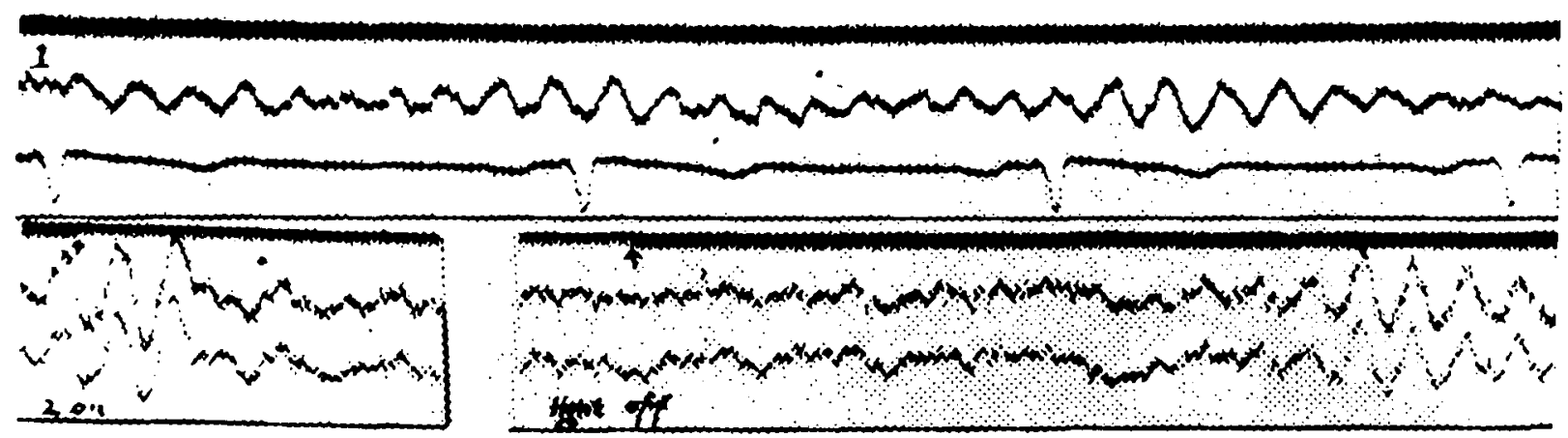

Figure 2: First human EEG record published in America. Upper line shows alpha waves waxing and waning; bottom two lines show blocking of the alpha waves with visual stimulation (Jasper and Carmichael, 1935). 


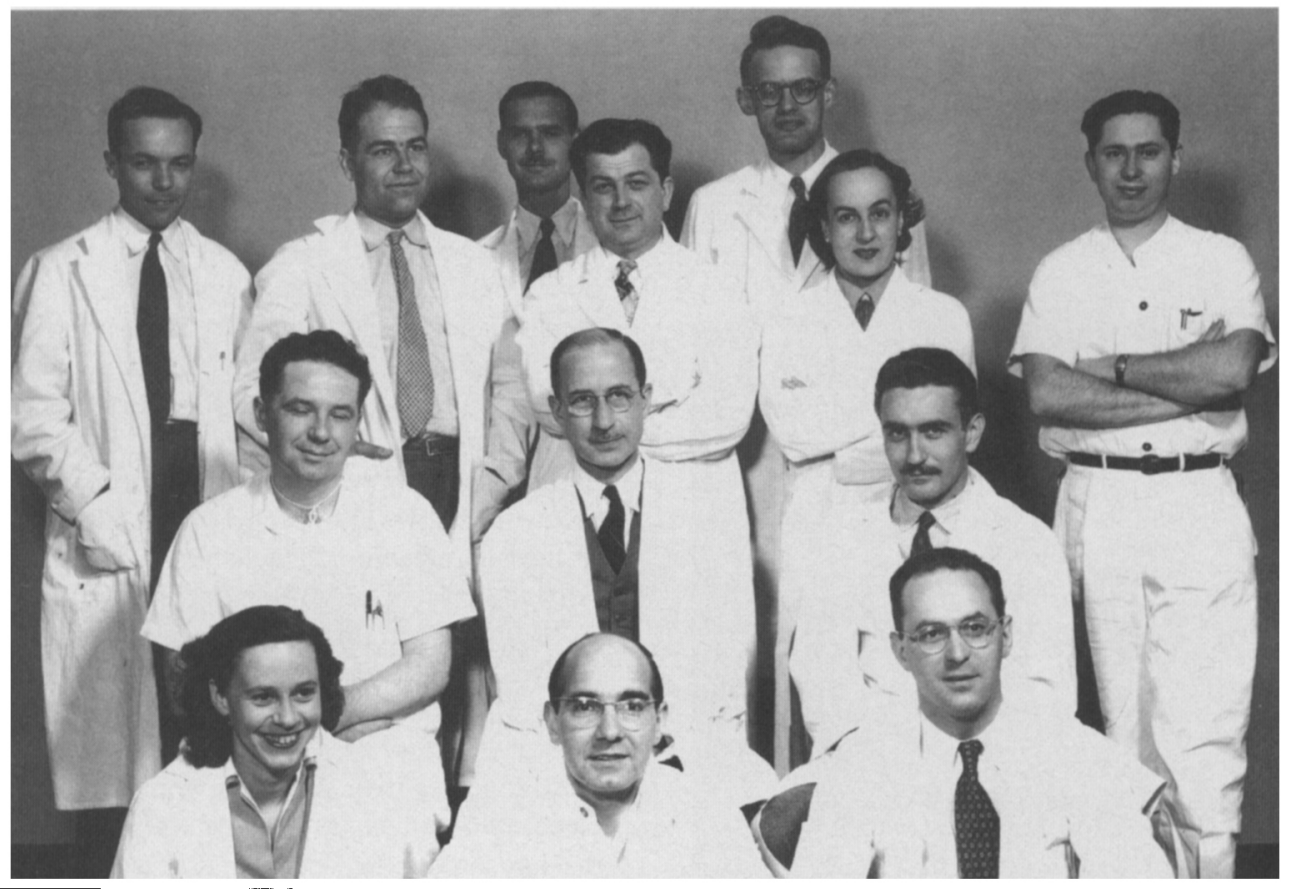

Figure 3: Herbert Jasper and research fellows in the laboratory of neurophysiology at the Montreal Neurological Institute (1952); Top row, left to right: J. Courtois (Canada), Gloor (Switzerland), Hunter (Australia), K. Tukel (Turkey), Ingvar (Sweden), M. Tukel (Turkey), Hanbery (USA); Middle row: Stoll (USA), Jasper (Canada), Ajmone-Marsan (Italy); Front row: A. Courtois (France), Oeconomos (Greece), Feindel (Canada)

drug mescaline determined him to include brain chemistry in his future program of brain research. At the University of Oregon he gained a Master's degree for a thesis titled "Perseveration and its Relation to Depression and Introversion". He then went on to the University of Iowa, taking his first doctorate in 1931 on a problem relating to bilateral coordination of movements in normal patients and in those with severe stuttering.

In 1930, at a meeting of the American Physiological Society, Herbert Jasper had a fortunate meeting with Alexandre and Andrée Monnier who had been studying in St. Louis with Gasser on a Rockefeller Fellowship. Herbert accepted their invitation to join them in Paris, for which he obtained a fellowship from the Rockefeller Foundation.

From 1931 to 1932, he worked in Paris with the Monniers and Louis Lapicque, to study in detail the phenomenon of chronaxie in shellfish using their cathode ray oscilloscope newly acquired in St. Louis. He enhanced his overseas studies at the marine biological stations in Brittany and in Naples. He also discovered the sport of sailing, with Lapicque on his ocean-going yacht, the "Axon", as well as with the Monniers and Jacques Monod.

From 1932 to 1938 Herbert Jasper worked at Brown University in Providence, Rhode Island developing an EEG laboratory. During the summers of 1932 and 1933 at the Woods Hole Marine Biological Laboratories he completed research toward his doctoral thesis. With Leonard Carmichael, he published, in 1935 in Science, the first paper in the United States on the human EEG. (Figure 2) It was a three-page note in which they described how they had confirmed and amplified Hans Berger's findings in electroencephalography which he had published in numerous reports between 1929 and 1933. They noted "spontaneous" fluctuations in magnitude of the alpha waves, the reduction of these waves by visual stimulation, and their consis- tent frequency in the same individual on repeated examinations. "In one or two pathological cases which we have studied, a frequency of alpha waves as low as 2-3 per second has been observed." (This was evidently an early example of delta waves associated with brain damage). They cautiously predicted, "It may well be that the electroencephalograms of the sort described in this note may prove significant in psychology and clinical neurology. It is even possible that this technique may provide information in regard to brain action which will be comparable in significance to the information in regard to heart function which is provided by the electrocardiograph." A few months later, the group in Boston including Gibbs, Davis, Forbes and Lennox reported on the value of EEG in the diagnosis of epilepsy. Jasper and his team promptly confirmed these findings with their new apparatus.

When Jasper returned to Paris in 1935 to defend his thesis, he added a supplementary thesis on the work he had carried out with his team on EEG. Shortly after that he met Hans Berger, whose early reports on the discovery of electroencephalography had been received with considerable skepticism. Jasper also visited at Cambridge Edgar Adrian and Brian Matthews who had expanded Berger's original findings and given physiological credence to this exciting technique of recording electrical waves from the head. ${ }^{1}$

\section{Work at the Montreal Neurological Institute}

In 1936 , by the age of 30 , Herbert Jasper had many achievements to his credit. He had gained two doctorate degrees, published more than a score of scientific papers, established his own EEG laboratory and was recognized as one of the pioneers in America in this field. He had become known to most of the main figures in neurophysiology for his research on both basic and clinical aspects of nervous system. In 1937, Herbert had a chance 


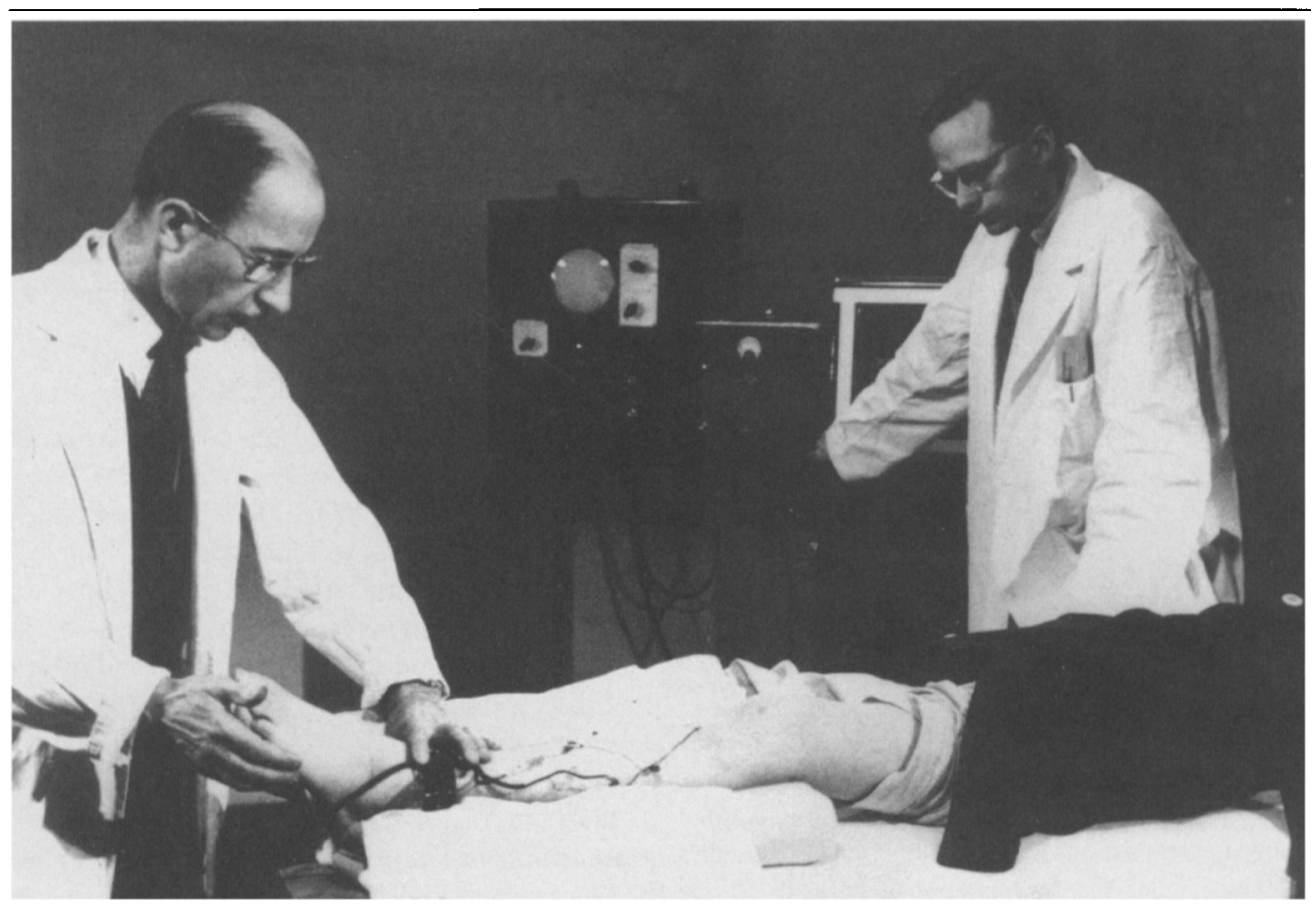

Figure 4: Herbert Jasper and research fellow David Hubel in the electromyographic laboratory, Montreal Neurological Institute (1953).

encounter with Wilder Penfield who had been invited to Brown University to give a seminar in the Psychology Department. Penfield described his results on electrical stimulation to map the cortex in conscious patients during surgery for the treatment of focal epilepsy. He had approached this problem by the study of brain scars which he examined by the histological techniques of Cajal and Hortega. He had also learned from Otfrid Foerster in Germany the method for cortical stimulation during surgery with the patient under local anesthesia - an acquisition which would prove to be the foundation of his future career in the study of human brain physiology and of his quest for a surgical cure of focal epilepsy. After the seminar at Brown, Penfield, invited to view Jasper's EEG laboratory, was taken to a basement room in which there was a maze of chicken wire. He described it as follows: "It served, I was told, as an electrical shield. Inside the maze was a young man, moving about like a bird in an aviary. This was a rare bird, a rara avis, Herbert Jasper, a young man driven by one creative idea after another. He could, he said, localize the focus of an epileptic seizure by the disturbance of brain rhythms outside the skull. I doubted that but hoped it might be true". ${ }^{6}$ The upshot of this unexpected meeting was that Jasper selected two patients for Montreal in which he had localized the epileptic focus by EEG. Penfield operated and confirmed the localization. Jasper then arranged with Penfield to travel to Montreal during the middle of the week with a portable EEG unit to record epileptic activity in Penfield's patients. This collaboration went well, but the arrangement was awkward and temporary, Penfield describing it as "our almost unthinkable commuters research project". Herbert Jasper was particularly attracted to the opportunities and atmosphere for brain research at the new Institute and not least by the skiing and sailing weekends which were part of the Institute's lifestyle. Penfield obtained funds from the Rockefeller Foundation, matched by a generous Montreal citizen, J.W. McConnell, to construct an annex off the basement of the Institute dedicated to clinical electroencephalography and to the study of epilepsy and mental illness - probably one of the first such units specifically designed for that purpose.

The EEG Department was opened by a symposium in February 1939, the meeting being continued in the Laurentian Mountains, the first of the legendary annual ski meets of the Eastern EEG Association, which have continued ever since.

Of the next three decades in Montreal, Herbert Jasper wrote, "My time with Wilder Penfield and his family, in which I became an adopted member, working with his splendid enthusiastic staff and hundreds of colleagues and students from all over the world who worked with us, was certainly a most pleasant and productive 27 years of my life."3 Jasper flourished in Penfield's multidisciplinary institute where the basic scientists worked closely with clinicians. As Penfield was fond of saying, epilepsy became their teacher.

They were soon examining a thousand or more patients in the EEG Department each year and becoming more and more involved in cortical recording during surgery. Feeling the need for more medical training, Herbert Jasper enrolled as a medical student, taking his MDCM at McGill in 1943, while continuing with his heavy program of clinical and laboratory work. During this time, he was also engaged in wartime research at the Institute on air transport for head injuries, antibiotics for treatment of brain wounds, electromyography of nerve injuries and studies on the physiology of air-pilot blackout.

In the decade after the war, more than a hundred research fellows and trainees from many countries came to the Institute. Many worked in the EEG and neurophysiological laboratories with Herbert Jasper. (Figure 3) Their publications covered the topics of thalamic-cortical connections, the intralaminar reticular formation and the limbic system, using electronic techniques of unit cell recording, all directed toward unravelling the neural 


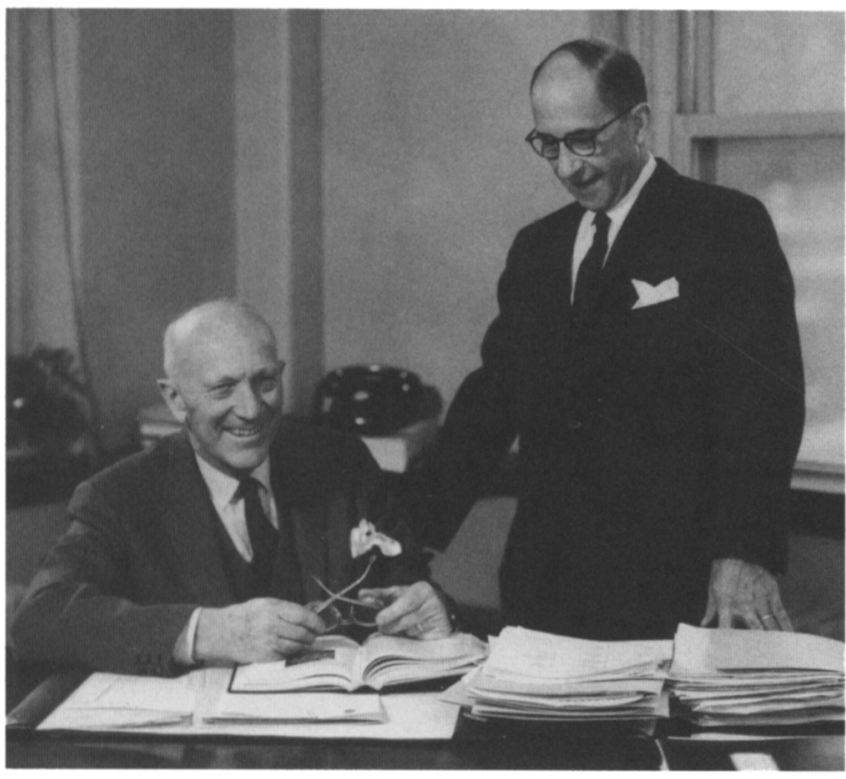

Figure 5: Wilder Penfield and Herbert Jasper at the time of publication of their monograph, Epilepsy and the Functional Anatomy of the Human Brain (1954).

mechanisms of epilepsy. ${ }^{3,11}$ (Figure 4) In 1954, a monograph with Wilder Penfield on Epilepsy and the Functional Anatomy of the Human Brain, summarized their experience with hundreds of surgical cases of epilepsy and became the most widely used text in this field. ${ }^{9}$ (Figure 5) A publication on Brain Mechanisms and Consciousness derived from a symposium in 1954, of which Jasper was the principal organizer. ${ }^{13} \mathrm{He}$ presented his studies on the thalamic reticular system, which has since become recognized as such an important inhibitory system in relation to epilepsy.

After the war, as the Institute returned to a normal pattern, a new MNI recruit, Allan Elliott, a brain chemist, expanded the biochemistry laboratories into the first research unit for neurochemistry, endowed in perpetuity through the efforts of Wilder Penfield by annual grants from the Donner Canadian Foundation.

Herbert Jasper's investigative career led him more and more into basic research on the electrical activity of single nerve cells recorded from implanted electrodes in different brain regions of experimental animals and into collaboration with the neurochemical team under Allan Elliott. Part of this saga involved Ernst and Elizabeth Florey who were invited in 1953 by Elliott to come to the MNI to study an inhibitory factor which they had found in brain extract. ${ }^{12}$ In 1955, the Floreys and Hugh McLennan (providing his expertise in microelectrode recording from nerve cells) characterized the inhibitory effects of "Factor I" on peripheral and central synaptic transmission. Alva Bazemore, a medicinal chemist from Merck, identified Florey's factor as gamma-amino-butyric acid (GABA) in 1956." This was quickly followed by the work of Iwama and Jasper confirming its inhibitory action on the cerebral cortex. ${ }^{12}$

As Herbert Jasper noted in his review of research at the MNI in 1954-1955, "the reports from Drs Florey and McLennan on the isolation of the substances from brain tissue which have strong inhibitory or excitatory effects on the activity of the central nervous system were outstanding ... the isolation of a naturally occurring inhibitory substance in the brain, if confirmed by further study, may be a discovery of major consequence, not only for our understanding of normal brain function, but also for the rational treatment of brain disorders." 12 This discovery, of course, was most relevant to other studies at the Institute, both experimental and clinical, which focused on the mechanism and pharmaceutical therapy of epilepsy. The complex relationship between excitatory amino acids and GABA with its range of receptors and receptor subunits continues to be the subject of extensive investigation. ${ }^{13}$

\section{Move to the Université de Montréal}

Herbert reestablished his contacts in France when he moved to Paris with his family in 1960 to become the Executive Secretary of IBRO, the International Brain Research Organization. This was incorporated in 1960 by the Parliament of Canada, with Herbert Jasper, Wilder Penfield and Frank McIntosh as the petitioners for the Parliamentary Bill.

After returning from Paris, Herbert Jasper decided in the mid1960s to focus on experimental neurophysiology, concentrating on the combination of neurochemical and microelectrode techniques that he had developed so effectively with Allan Elliott and his team. In 1964, he moved to the Université de Montréal where an enthusiastic new group in neurosciences, supported by the Medical Research Council of Canada, had been formed under the leadership of Jean-Pierre Cordeau, a former Fellow of the MNI. Here Jasper's work continued to flourish while his fluent knowledge of French and his continuing contact with the European neuroscientists made this a workable transition. He continued as Consultant in Neurophysiology at the Montreal Neurological Institute; in 1964 to 1966 he carried out with Gilles Bertrand pioneer unit cell recordings from the basal ganglia in patients undergoing stereotaxic treatment for Parkinson's Disease. ${ }^{10}$ (Figure 6)

During the decades of his 70 s and 80 s, Herbert Jasper persisted tirelessly in his research at Université de Montréal. His attendance at conferences and lectures was often characterized by pithy comments on the topics under discussion. Because of his fundamental training in laboratory neurobiology, he offered

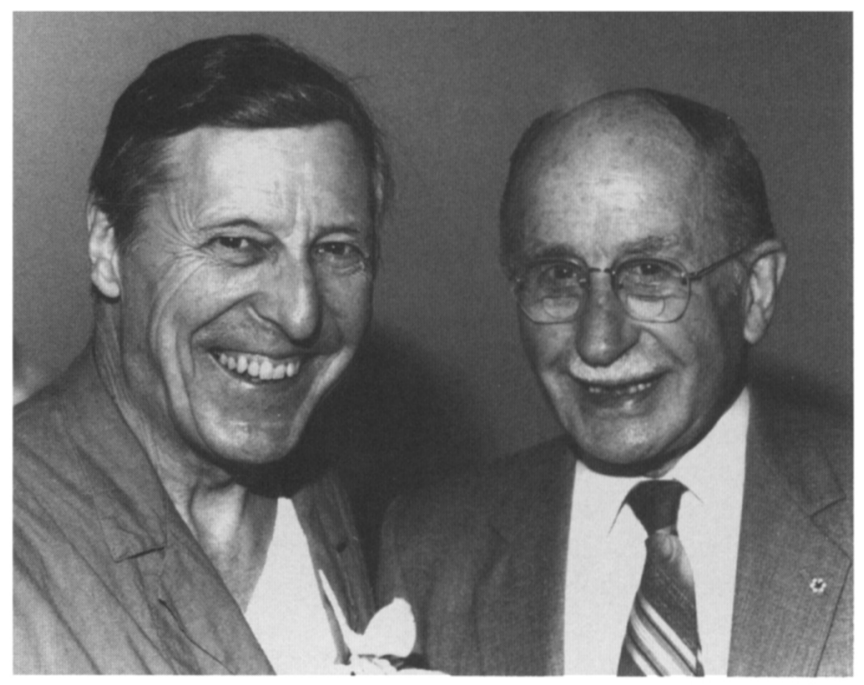

Figure 6: Gilles Bertrand and Herbert Jasper in 1988. They collaborated from 1964 to 1966 on pioneer studies of unit recording from basal ganglia neurons in patients undergoing stereotaxic surgery for Parkinson's disease. 
valuable critiques of new work that were sometimes based on research topics which he and his collaborators had previously examined. He provided superb summaries and reviews of symposia from his well-informed perspective. ${ }^{2,8}$

Herbert Jasper continued in active health up to a few months before his 93rd birthday when on March 11, 1999, he succumbed to a sudden cardiac attack.

\section{Worldwide Recognition}

Herbert Jasper collected prizes, awards, distinctions, honorary degrees and worldwide recognition for the panoramic role he had played over many decades in fostering and promoting brain sciences at national and international levels. Among these were the Ralph Gerard Prize of the Society for Neuroscience, the McLaughlin Medal of the Royal Society of Canada, the FNG Starr Award of the Canadian Medical Association and the Albert Einstein World Science Award of the World Cultural Council. He was appointed an Officer of the Order of Canada, elected into the Canadian Medical Hall of Fame, and as Le Grand Officier de l'Ordre National du Québec. His work in epilepsy was recognized by the William G. Lennox Award of the American Epilepsy Society, the Carl Spencer Lashley Award of the American Philosophical Society and the research award sponsored by the Milkin Family Medical Foundation and American Epilepsy Society.

As an editorial summary of his scientific autobiography noted, "Herbert Henri Jasper dedicated his life to studies of the brain in relation to the mind and behavior. He pioneered the establishment of the electroencephalogram for the study of the electrical activity of the brain in relation to states of consciousness, learning, and epileptic discharge. He used microelectrodes to record from single brain cells and synapses, combined with studies of neurochemical mechanisms involved in the control of brain activity".'

It may be added that he shared a long and fruitful partnership with Wilder Penfield and his MNI team to help in the treatment of patients with epilepsy. ${ }^{3} \mathrm{He}$ trained scores of clinical and research fellows from Canada, United States and other parts of the world in the intricacies of experimental neurophysiology and electroencephalography. ${ }^{14} \mathrm{He}$ was a driving force in the scientific programs at the MNI over a period of almost thirty years and for another thirty years he contributed vigorously as a leader in the research group in neurosciences at Université de Montréal. From his earliest work, ${ }^{15}$ he continued to be intrigued by the brain's autonomous rhythms and their changes during different levels of consciousness, their variations in excitatory and inhibitory states and their responses to reverberations in the brainstem and thalamic reticular formations. And finally, Herbert
Jasper assiduously devoted his efforts to fostering international friendship and scientific collaboration through the medium of the neurosciences, enthusiastically helping to effect this as a founding member of the International Brain Research Organization. His prodigious contributions will be appreciated by the world community of brain science for years to come.

\section{REFERENCES}

1. Jasper H.H. Some highlights of 70 years in neuroscience research. In: Squire LR, ed. The History of Neuroscience in Autobiography. Vol. 1. Washington, DC: Society for Neuroscience. 1996; 318-346.

2. Jasper H.H. Philosophy or physics - mind or molecules. In: Worden FG, Swazey, JP, Adelman G, eds. The Neurosciences: Paths of Discovery. Cambridge, Mass: MIT Press, 1975; 403422.

3. Jasper H.H. History of the early development of electroencephalography and clinical neurophysiology at the Montreal Neurological Institute: the first 25 years, 1939-1964. Can J Neurol Sci 1991; 18, No. 4 (Supplement): 533-548.

4. Gloor P. H.H. Jasper, neuroscientist of our century. In: Neurotransmitters and Cortical Function: from Molecules to Mind. Avoli M, Reader TA, Dykes RW, Gloor P (eds). New York: Plenum, 1988: 1-13.

5. van Gelder N.M. H.H. Jasper: Modern concepts of epilepsy. In: Neurotransmitters and Cortical Function: from Molecules to Mind. Avoli M, Reader TA, Dykes RW, Gloor P (eds). New York: Plenum, 1988: 15-23.

6. Penfield W. Herbert Jasper. In: Cordeau JP, Gloor P, eds. Recent Contributions to Neurophysiology: International Symposium in Neurosciences in Honor of Herbert H. Jasper. EEG Clin Neurophysiol 1972; Suppl. 31: 9-12.

7. Jasper H.H., Carmichael L. Electrical potentials from the intact human brain. Science 1935; 81: 51-53.

8. Jasper H.H. Historical introduction: early efforts to find neurochemical mechanisms in epilepsy. In: Avanzini G, Engel J. Fariello R, Heinemann U, eds. Neurotransmitters in Epilepsy. New York: Elsevier Science Publishers, 1992: 1-8.

9. Penfield W, Jasper H. Epilepsy and the Functional Anatomy of the Human Brain. Boston: Little, Brown, 1954.

10. Jasper H.H., Bertrand G. Recording from microelectrodes in stereotaxic surgery for Parkinson's disease. J Neurosurg 1966; 24:219221.

11. Bazemore A.W., Elliott K.A.C., Florey E. Factor I and gammaamino-butyric acid. Nature, 1956; 178: 1052-3.

12. Feindel W. Brain physiology at the Montreal Neurological Institute: some historical highlights. J Clin Neurophysiol 1992; 9(2): 176194.

13. Florey E. GABA: history and perspectives. Can J Physiol Pharmacol 1991; 69: 1049-56.

14. Jasper H.H. The early development of neuroscience in Canada. Can J Neurol Sci 1985; 12: 221-229.

15. Jasper H.H. Cortical excitatory state and synchronism in the control of bioelectric autonomous rhythms. Cold Spring Harb. Symp Quant Biol 1936; 4: 320-338. 